\title{
Potential Mechanism of Action of Current Point-of-Care Autologous Therapy Treatments for Osteoarthritis of the Knee-A Narrative Review
}

\author{
Jennifer Woodell-May ${ }^{1, *}$, Kathleen Steckbeck ${ }^{1}$ and William King ${ }^{2}$ \\ 1 Zimmer Biomet, 56 East Bell Drive, Warsaw, IN 46580, USA; kathleen.steckbeck@zimmerbiomet.com \\ 2 Owl Manor, 720 East Winona Avenue, Warsaw, IN 46580, USA; william.king@owlmanormedical.com \\ * Correspondence: jennifer.woodell-may@zimmerbiomet.com
}

Citation: Woodell-May, J.; Steckbeck, K.; King, W. Potential Mechanism of Action of Current Point-of-Care Autologous Therapy Treatments for Osteoarthritis of the Knee-A Narrative Review. Int. J. Mol. Sci. 2021, 22, 2726. https://doi.org/ $10.3390 /$ ijms 22052726

Academic Editor: Masato Sato

Received: 1 February 2021

Accepted: 23 February 2021

Published: 8 March 2021

Publisher's Note: MDPI stays neutral with regard to jurisdictional claims in published maps and institutional affiliations.

Copyright: ( $\odot 2021$ by the authors Licensee MDPI, Basel, Switzerland. This article is an open access article distributed under the terms and conditions of the Creative Commons Attribution (CC BY) license (https:// creativecommons.org/licenses/by/ $4.0 /)$.

\begin{abstract}
Osteoarthritis (OA) is a progressive degenerative disease that manifests as pain and inflammation and often results in total joint replacement. There is significant interest in understanding how intra-articular injections made from autologous blood or bone marrow could alleviate symptoms and potentially intervene in the progression of the disease. There is in vitro an in vivo evidence that suggests that these therapies, including platelet-rich plasma (PRP), autologous anti-inflammatories (AAIs), and concentrated bone marrow aspirate (cBMA), can interrupt cartilage matrix degradation driven by pro-inflammatory cytokines. This review analyzes the evidence for and against inclusion of white blood cells, the potential role of platelets, and the less studied potential role of blood plasma when combining these components to create an autologous point-of-care therapy to treat OA. There has been significant focus on the differences between the various autologous therapies. However, evidence suggests that there may be more in common between groups and perhaps we should be thinking of these therapies on a spectrum of the same technology, each providing significant levels of anti-inflammatory cytokines that can be antagonists against the inflammatory cytokines driving OA symptoms and progression. While clinical data have demonstrated symptom alleviation, more studies will need to be conducted to determine whether these preclinical disease-modifying findings translate into clinical practice.
\end{abstract}

Keywords: platelet-rich plasma; autologous anti-inflammatory; concentrated bone marrow aspirate; osteoarthritis; intra-articular injection; mechanism of action

\section{Introduction}

Osteoarthritis $(\mathrm{OA})$ is a degenerative and disabling articulating joint disease that affects both younger, more active patients (e.g., patients with trauma or who have prolonged participation in highly demanding sports) and the elderly [1,2]. The disease is progressive and debilitating, eventually resulting in pain that may be so severe that restive sleep is impossible, along with life-altering loss of function.

Surgical intervention is clinically successful, and widely used, in treating severe degenerative OA; however, treatment modalities for less advanced OA are associated with varying rates of success. Current treatment options include non-steroidal anti-inflammatory drugs (NSAIDs), corticosteroid injections, and hyaluronic acid (HA) injections. Although these treatments can relieve pain temporarily for some OA patients, they may not address the biological mechanisms causing the disease [3].

Although OA is classified as a non-inflammatory disease, inflammation is implicated in many symptoms and in OA progression. Pro-inflammatory cytokines involved in OA development include interleukin-1 (IL-1), tumor necrosis factor alpha (TNF $\alpha$ ), interleukin-6 (IL-6), and interleukin-8 (IL-8) [4]. The cytokines associated with inflammation in OA, primarily interleukin- 1 beta (IL-1 $\beta$ ) and TNF $\alpha$, are also implicated in cartilage matrix breakdown [5]. These cytokines induce chondrocytes to produce matrix metalloproteinases 
(MMPs) that in turn are responsible for cartilage matrix degradation [6]. These cartilage matrix breakdown products in synovial fluid are thought to increase synovial inflammation [7], creating a positive feed-forward loop that increases inflammation and cartilage breakdown (Figure 1).

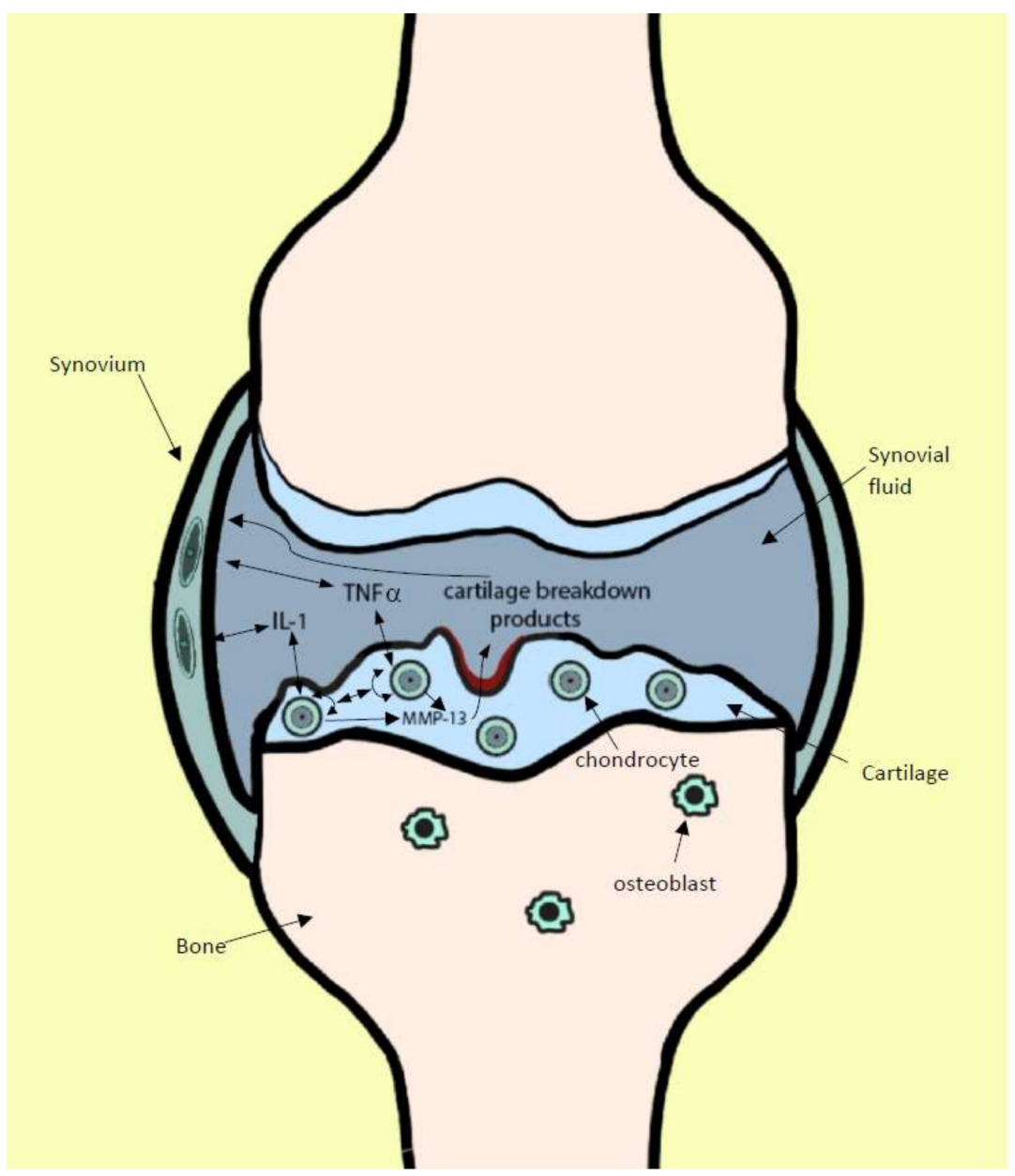

Figure 1. Model of feed-forward loop of pro-inflammatory cytokine-driven OA progression. IL-1 $\beta$ and TNF $\alpha$ bind to chondrocytes and induce expression of MMP-13. MMP-13 causes cartilage matrix breakdown. Cartilage breakdown products inflame cells in the synovium, inducing more production of IL-1 $\beta$ and TNF $\alpha$.

As IL-1 $\beta$ and TNF $\alpha$ play important roles in inflammation and cartilage breakdown, inhibition of these cytokines may limit inflammation and matrix degradation. Consequently, inhibition of these proteins may constitute an effective OA therapy. The anti-inflammatory cytokine interleukin-1 receptor antagonist (IL-1ra), a competitive IL-1 receptor antagonist, blocks the signaling activity of IL-1 while exhibiting no signal-inducing activity itself [8]. Soluble forms of the IL-1 receptor (sIL-1R) can also bind with IL-1, reducing IL-1 biologic activity by preventing it from binding to surface receptors on the cells [9]. Moreover, soluble forms of the cell receptors for TNF $\alpha$, known as sTNF-RI and sTNF-RII, can bind to $\mathrm{TNF} \alpha$, preventing $\mathrm{TNF} \alpha$ surface receptor binding and thus inhibiting cell signaling [10].

Over the past two decades, preparations from autologous blood or bone marrow to create platelet-rich plasma (PRP), autologous anti-inflammatories (AAIs), and concentrated bone marrow (cBMA or BMAC) have been studied in order to treat osteoarthritis. Each of these formulations are created from similar starting materials by combining plasma, platelets, white blood cells (including early lineages) in various combinations. Each formulation is in on a spectrum of similar mechanistic approaches to treating OA. Regulatory approval to treat OA vary for these formulations depending on the region in the world. 
The purpose of this review is to summarize the data that exist for each of these classes of autologous therapies and how each may intervene in the OA disease process.

\section{Methods}

Search terms in both PubMed database and Google Scholar included "platelet-rich plasma", PRP, osteoarthritis, "cell culture", preclinical, and "mechanism of action" in various combinations. The same combinations were repeated for "concentrated bone marrow aspirate", "cBMA", "BMAC", "autologous anti-inflammatory", and "AAI". Additionally, the authors' own knowledge and work in the field was included when relevant. A focus was made on the specific role that these therapies play in the treatment of OA, and therefore cartilage-specific studies were only included to expand on the potential role that cartilage repair has during treatment of OA.

\section{Results}

\subsection{Platelet-Rich Plasma}

Platelet-rich plasma (PRP), or platelet concentrate, is defined as an autologous therapy prepared point of care that contains a concentration of platelets higher than whole blood. This review will focus on PRP prepared by centrifugation that takes advantage of the density differences between the elements in peripheral blood allowing for separation of components. In general, PRP can be divided broadly into two classifications. The first preparation class is created with "slow" centrifugation speeds (e.g., $1500 \mathrm{rpm}$ for $5 \mathrm{~min}$ ) and have platelet concentrations $2-3$ times above baseline collected in blood plasma (plateletpoor plasma; PPP), and with very few red blood cells or white blood cells. These PRPs are yellow in color. The second classification is prepared from "hard" spin cycles (e.g., $3200 \mathrm{rpm}$ for $15 \mathrm{~min}$ ) resulting in PRPs with platelet concentrations 5-9 above whole blood and typically with white blood cells also above baseline levels. This method typically contains some RBC and are red in color. One popular classification method to discern these two PRPs has focused on the differences in white blood cell concentrations, calling the products with low white blood cell concentrations leukocyte-poor platelet-rich plasma (LP-PRP) and those with higher WBC concentrations as leucocyte-rich platelet-rich plasma (LR-PRP). An evaluation of blood components can be compared by complete blood counts (CBC) (Table 1). Platelet concentrates can also be activated to form a fibrin clot, often referred to as platelet-rich fibrin (PRF). These gel products are often utilized in direct application to a surgical or wound site [11], but are not included in this OA review.

Table 1. Complete blood counts (CBC) of common autologous therapies. (PPP: platelet-poor plasma; LP-PRP:leucocyte-poor platelet-rich plasma; LR-PRP: leucocyte-rich platelet-rich plasma; APS: autologous protein solution; ACS: autologous conditioned serum; BMA: bone marrow aspirate; cBMA: concentrated bone marrow aspirate; BL: below lower limit; NC: not calculated, NM: not measured).

\begin{tabular}{|c|c|c|c|c|c|c|c|c|}
\hline & WBC (k/ul) & PLT (k/ul) & RBC (M/ul) & IL-1ra (pg/mL) & $\begin{array}{l}\text { sIL-1RII } \\
(\mathrm{pg} / \mathrm{mL})\end{array}$ & $\begin{array}{l}\text { sTNF-RII } \\
\text { (pg/mL) }\end{array}$ & $\begin{array}{c}\text { IL-1 } \beta \\
(\mathrm{pg} / \mathrm{mL})\end{array}$ & $\begin{array}{c}\text { IL-1ra:IL-1 } \\
\text { ratio }\end{array}$ \\
\hline $\begin{array}{l}\text { Whole blood } \\
\text { [12] }\end{array}$ & $5.4 \pm 1.8$ & $175 \pm 70$ & $5.5 \pm 1.1$ & $5665 \pm 2318$ & $7135 \pm 1766$ & $1125 \pm 253$ & $3.4 \pm 2.0$ & $4842 \pm 2756$ \\
\hline PPP [13] & $0.1 \pm 0.0$ & $28 \pm 9.3$ & $0.00 \pm 0.00$ & $296 \pm 141$ & $19,922 \pm 2938$ & $3080 \pm 635$ & $\mathrm{BL}$ & $\mathrm{NC}$ \\
\hline LP-PRP [13] & $1.5 \pm 2.0$ & $399 \pm 108$ & $0.04 \pm 0.06$ & $673 \pm 741$ & $15,596 \pm 2159$ & $2894 \pm 689$ & $\mathrm{BL}$ & $\mathrm{NC}$ \\
\hline LR-PRP [12] & $28.1 \pm 6.9$ & $1745 \pm 439$ & $0.9 \pm 0.3$ & $22,395 \pm 12,900$ & NM & $\mathrm{NM}$ & $3.5 \pm 1.0$ & $6369 \pm 2321$ \\
\hline APS [12] & $46.5 \pm 14.0$ & $707 \pm 444$ & $1.5 \pm 1.1$ & $30,853 \pm 16,734$ & $20,483 \pm 5819$ & $9492 \pm 1387$ & $3.8 \pm 0.8$ & $8535 \pm 3999$ \\
\hline ACS [12] & $0.0 \pm 0.0$ & $14 \pm 6$ & $0.0 \pm 0.0$ & $1618 \pm 675$ & $15,678 \pm 2356$ & $2696 \pm 679$ & $14.7 \pm 14.8$ & $291 \pm 256$ \\
\hline BMA [14] & $22 \pm 10$ & $116 \pm 30$ & $4.1 \pm 0.3$ & $18,110 \pm 6681$ & $6768 \pm 1995$ & $1292 \pm 153$ & $3.0 \pm 1.1$ & $6154 \pm 1357$ \\
\hline cBMA [14] & $133 \pm 91$ & $885 \pm 201$ & $1.3 \pm 0.2$ & $73,978 \pm 39,464$ & $9814 \pm 3199$ & $3932 \pm 1301$ & $14.5 \pm 11.4$ & $5856 \pm 2745$ \\
\hline
\end{tabular}

As PRP first became popular in orthopedics, clinical use was focused on both hard (bone) and soft tissues (tendon, muscle, etc.) because the platelets concentrated contain growth factors (PDGF, VEGF, TGF- $\beta 1$, EGF) that are chemoattractive, proliferative, and 
angiogenic, therefore, playing a key role in signaling the wound healing cascade. When these mechanisms were translated into treating $\mathrm{OA}$, the initial belief was that the growth factors in platelets would stimulate chondrocyte cell growth in the cartilage, thereby healing cartilage defects. There is ample evidence that PRPs can induce chondrocyte proliferation $[15,16]$ in cell culture. However, chondrocyte proliferation effects have not yet translated into a clinical benefit when treating OA. PRP OA mechanism has evolved to include intervening in the inflammatory process. Interestingly, the factors that most likely contribute anti-inflammatory cytokines in PRP are found in the blood plasma and white blood cells and not in the platelets (Figure 2).

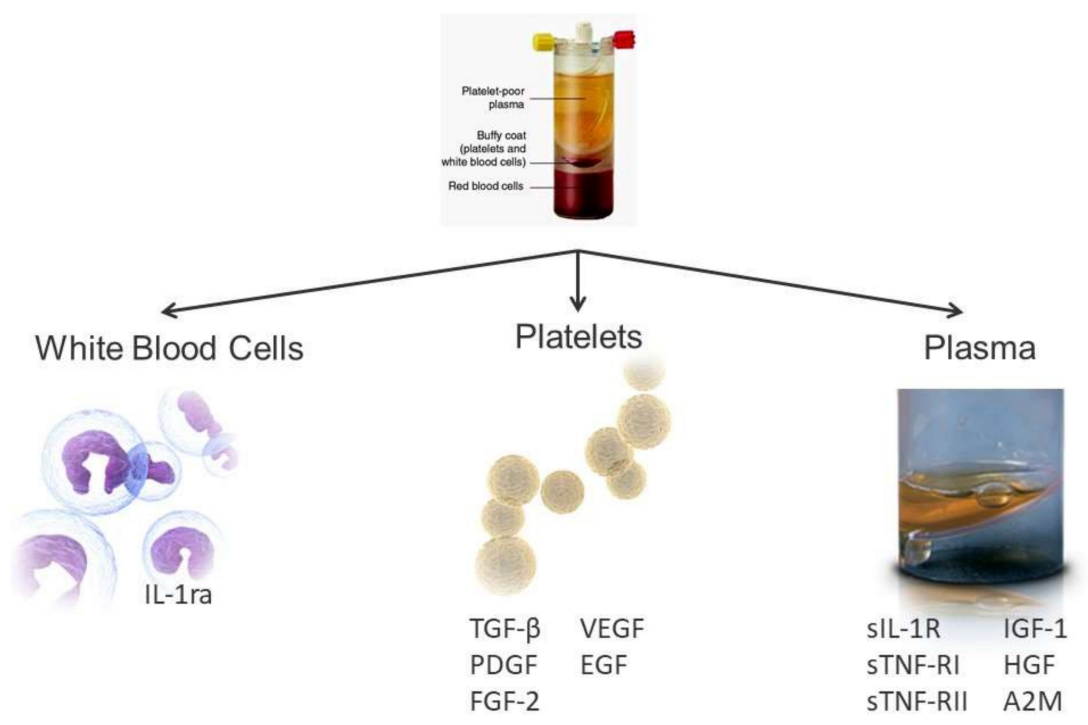

Figure 2. Cytokine contribution from components of blood used to make autologous therapies.

PRP in vitro mechanistic data in OA have focused on the differences between LP-PRP and LR-PRP. The cytokines found in a LP-PRP and LR-PRP reflect their platelet and white blood cell concentration (Figure 1). LP-PRP has lower concentrations of platelet-derived growth factors (PDGF, TGF- $\beta 1$ ) than LR-PRP due to lower platelet concentrations (Table 1). LR-PRP has more white blood cell-derived cytokines over LP-PRP that include both proinflammatory cytokines (IL-1 $\beta$, MMP-9) [17] and anti-inflammatory cytokines (IL-1ra) [12]. IL-1ra is produced from monocytes [18] and neutrophils [19]. Therefore, in order for a PRP to have high concentrations of IL-1ra, WBCs need to be included. In order to ensure that the PRP is not pro-inflammatory, the ratio of IL- $1 \beta$ and IL-1ra is important. In a common LR-PRP, the amount of IL- $1 \beta$ is $3.5 \pm 1.0 \mathrm{pg} / \mathrm{mL}$ while the IL-1ra is $22,395 \pm 12,900 \mathrm{pg} / \mathrm{mL}$, giving a ratio between the two of $6369 \pm 2321$ [12]. In order to evaluate how much IL-1ra is required to block the activity of IL-1 $\beta$, investigators intravenously injected IL- $1 \beta$ to induce fever in rabbits and then increasing concentrations of the antagonist IL-1ra to determine how much in excess was required. Symptoms were blocked $50 \%$ when IL-1ra was injected at 100-fold increase over IL-1 $\beta$ (100 IL-1ra:IL-1 $\beta$ ) and were completely blocked by 1000-fold excess of IL-1ra (1000 IL-1ra:IL-1 $\beta$ ) [20].

In addition to production of pro-inflammatory cytokines, in cell culture LR-PRP has demonstrated higher levels of synoviocyte cell death and pro-inflammatory cytokine production compared to LP-PRP or PPP [21]. As LR-PRP has higher concentrations of RBC, it has been observed that layers of RBC deposit on the top of a monolayer cell culture, inhibiting nutrient transfer, and could lead to increased cell death and stimulation of pro-inflammatory cytokines. Cell culture techniques with autologous therapies that contain higher red blood cell content can be improved by either suspending the treatment above the monolayer culture with a cell culture insert (Nunc ${ }^{\mathrm{TM}}$ Polycarbonate Membrane Inserts, Thermo Scientific ${ }^{\mathrm{TM}}$ ) or by creating a thrombin-activated releasate. Using these techniques, both LP-PRP and LR-PRP can stimulate chondrocyte cell proliferation [15,16]. 
Additionally, human intra-articular injections of LR-PRP to treat OA has not resulted in increased pro-inflammatory cytokines in synovial fluid or blood plasma [22].

A less lauded component of PRP that contributes anti-inflammatory cytokines is the platelet-poor plasma. All autologous therapies are collected in some volume of blood plasma (Figure 2). Blood plasma contains sIL-1R1, sTNF-RI, sTNF-RII, and A2M [12,23,24]. Interestingly, no matter what autologous therapy, these factors contributed from blood plasma will be present at least in concentrations similar to whole blood, and in some formulations increased levels over whole blood. When examining the anti-inflammatory mechanism of action in OA, the PPP contributes more anti-inflammatory cytokines than platelets. This is a novel approach to understanding the activity of a LP-PRP product in the treatment of OA.

The in vitro positive effects on chondrocytes has translated into demonstrated benefit in animal models of chondral defects $[25,26]$. PRP has also demonstrated improved histology scores compared to saline in collagenase-induced OA rabbit model [27] and ACL transection rabbit model [28]. As treatment of OA is often focused on the alleviation of pain, in a randomized control trial in dogs with naturally occurring OA, PRP treated dogs had significant decrease in lameness grades compared to saline control subjects [29].

While there has been evidence of intra-articular injections of both LR-PRP and LPPRP $[30,31]$ providing clinical benefits for patients with knee OA pain, to date, there have been no correlation between any component of the PRP to clinical outcomes. The question still remains whether platelets, white blood cells, or, in fact, the blood plasma, contains the necessary ingredients to treat knee OA pain or to have any disease-modifying effect.

\subsection{Autologous Anti-Inflammatory}

Autologous anti-inflammatories (AAIs) are autologous blood-derived technologies that focus on concentrating high levels of anti-inflammatory cytokines [32,33]. As the focus on platelet-rich plasma is to concentrate platelets, the AAI designation was created to differentiate from products focused on platelets to those focused on the concentration of anti-inflammatory cytokines. As mentioned earlier, IL-1ra is produced from monocytes and [18] and neutrophils [19]. IL-1ra correlates to the number of WBCs contained in the output [34]. Therefore, AAIs typically utilize strategies to maximize WBC or to collect cytokines produced from WBCs.

Two examples of AAIs are autologous protein solution (APS) and autologous conditioned serum (ACS) [12]. APS is processed through a two-step centrifugation method where anticoagulated peripheral blood is centrifuged to isolate a leukocyte-rich buffy coat suspended in plasma. The buffy coat is mixed with polyacrylamide beads to absorb water; the output is then centrifuged a second time creating a WBC concentrate output suspended in a concentrated PPP $[33,35]$. APS is designed as a point-of-care single injection OA therapy $[36,37]$. ACS is produced by incubating venous blood at $37^{\circ} \mathrm{C}$ in borosilicate glass-bead containing tubes for 6-24 h. The blood clots and the WBCs expel IL-1ra and other cytokines. Following incubation, tubes are centrifuged and serum is removed, aliquoted into syringes, and stored frozen $-20^{\circ} \mathrm{C}$ for future multiple injections [32]. The major difference between APS and ACS is that APS output contains WBCs and ACS is cell-free serum collected from incubated WBCs.

The composition of AAIs is designed to inhibit the synergistic feed-forward progression of IL- $1 \beta$ and TNF- $\alpha$ by concentrating their respective antagonists (IL-1ra, sIL-1RII, sTNF-RI, and sTNF-RII) as well as multiple other cytokines and growth factors $[32,38]$ with the goal of intervening in the pro-inflammatory cytokines (IL-1 $\beta$ and TNF $\alpha$ ) that cause the degradation of OA [39] (Table 1).

Since AAIs have been specifically created with OA treatment in mind, there is an extensive amount of preclinical data supporting their mechanism of action of intervening in the IL- $\beta$ and TNF $\alpha$ catabolic pathways described earlier. For example, APS has been shown to reduce MMP-13 production from IL-1 $\beta$ and TNF $\alpha$-stimulated chondrocytes [35] and decreased IL-8 production from IL-1 $\beta$-stimulated activated macrophages [40]. AAIs have 
also demonstrated ability to reduce matrix degradation. In a stimulated equine cartilage and synovium explant co-culture, AAIs significantly downregulated IL- $1 \beta$ expression in cartilage, reduced catabolic cartilage production of PGE2, and downregulated MMP-1 in the synovium [41]. AAIs also upregulated type II collagen and aggrecan expression [41]. AAIs provided chondroprotective effects and decreased matrix degradation in cartilage explants treated with IL- 1 and TNF $\alpha[38,41]$.

When translating cell culture experiments into animal models, an intra-articular injection of APS demonstrated cartilage matrix protection by improved cartilage histology scoring compared to animals treated with saline in both a meniscal-tear OA model [42] and IL-1 $\beta$-induced OA model [43] in athymic rats. Single injections of APS have also demonstrated significant improvement in lameness compared to a single injection of saline in both equine [44] and canine [45] studies.

AAIs have demonstrated early clinical evidence linking cytokine and cellular content and clinical response in patients with OA. Wasai et al. found that the IL-1ra concentration in APS positively correlated with changes in the clinical outcome scores in subjects with knee OA [46]. In a clinical study of OA subjects treated with a single injection of APS, characterization analysis showed $85.7 \%$ of subject's APS had an IL-1ra:IL-1 ratio greater than 1000 or a WBC count greater than $30 \mathrm{k} / \mu \mathrm{L}$. These subjects were also high OMERACTOARSI clinical responders six months post-injection (Figure 3) [34,47]. Interestingly, this is the same ratio (1000 IL-1ra:IL-1 $\beta$ ) that demonstrated complete blockage of an IL-1 $\beta$ feverinduction model in rabbits [20]. These early results suggest that WBC, and consequently IL-1ra concentrations, can improve outcomes in OA subjects.
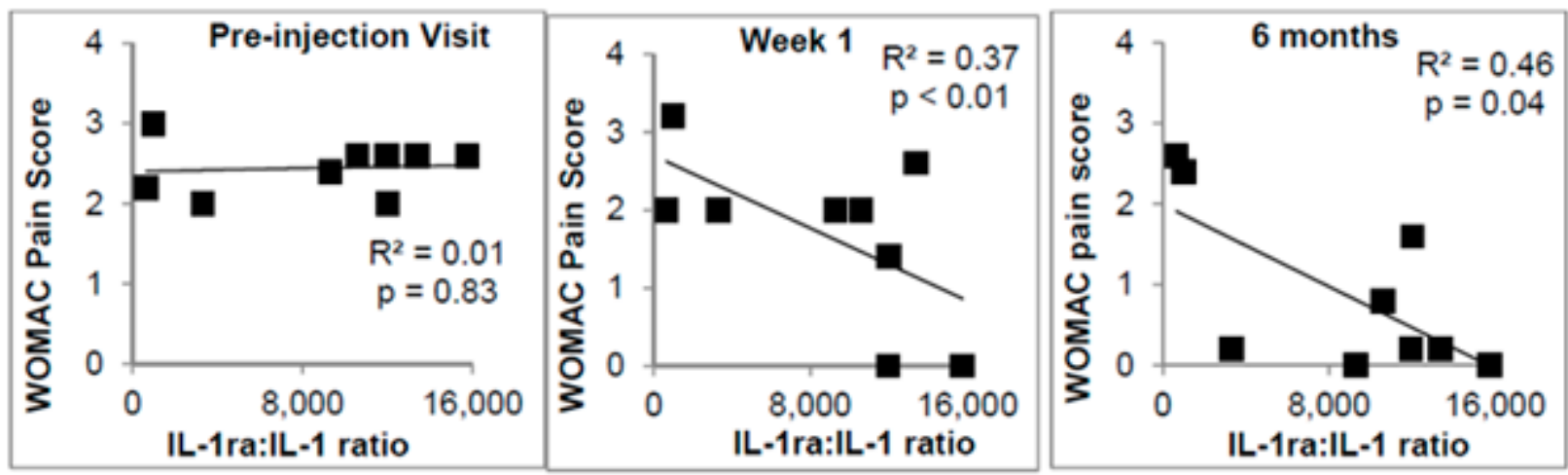

Figure 3. Correlation of WOMAC pain score and ratio of IL-1ra:IL-1 $\beta$ injection in OA subjects $[34,47]$.

Multiple clinical trials in the management of knee OA have been completed using AAIs as they have proven capable of producing high concentrations of anti-inflammatory cytokines from healthy subjects as well as subjects diagnosed with OA [32,33,46] Angadi et al. has recently reviewed and compared the current landscape of AAI clinical evidence and concluded their safety profiles satisfactory for clinical use and presented similar risk profiles of general intra-articular injections [48]. Two knee OA randomized controlled trials of ACS intra-articular injections, Yang et al. and Baltzer et al., demonstrated OA symptom improvements of ACS patients over placebo injections $[49,50]$. Several studies of a single injection of APS in knee OA have also demonstrated clinical benefits [36,37,51-53].

\subsection{Concentrated Bone Marrow Aspirate}

Devices that concentrate bone marrow aspirate have been explored to address osteoarthritis in preclinical models [54-58] and clinical trials [59-62]. Understanding what is in cBMA could inform how it might address osteoarthritis. The first proposed MOA for cBMA in treating OA was attributed to "stem cells [63]." However, cBMA contains a low number of stem cells in comparison to culture-expanded stem cell approaches [64]. An emerging understanding of cBMA is that it is a WBC, progenitor cell, and platelet-rich product which enables it to contain a high concentration of anti-inflammatory cytokines 
and anabolic growth factors [65]. Understanding that cBMA is in the same spectrum of options with PRPs and AAIs will help scientists and clinicians better understand the potential of this option.

The output of cBMA devices is determined by the components of bone marrow, the surgeon's aspiration technique, and the devices used to concentrate the cells and platelets. Bone marrow is a complex tissue made of hematopoietic stem cells (HSCs) which form blood [66], mesenchymal stem cells (MSCs) which form connective tissues [67], endothelial progenitor cells (EPCs) which form blood vessels [68], WBCs of mixed phenotypes, and platelets. Ultimately, the function of bone marrow is to create new blood cells. Stem cells are rare in bone marrow: Caplan has estimated that 1:10,000 cells in bone marrow is an MSC in newborns and that percentage declines with age [69]. It is important to note that the same white blood cells and platelets that are in bone marrow migrate to the blood stream. They are connected and part of the same system [70]. A surgeon's bone marrow aspiration technique impacts what cells are obtained for processing. It is not possible to obtain pure bone marrow without some peripheral blood dilution. Hernigou and colleagues have shown that smaller volume bone marrow draws, smaller volume syringes, and changing aspirate locations can minimize the dilution of bone marrow cells with peripheral blood [71]. Furthermore, different locations from aspiration could vary the cellular content of bone marrow aspirate [72]. While these techniques have been shown to be "best practices", these approaches are considered by some surgeons to be not pragmatic. Therefore, it is likely that many surgeons may be delivering a product that is closer to a blood-derived PRP than cBMA.

Providing bone marrow stem cells (BMSCs) have been one of the rationales proposed as for the intra-articular injection of cBMA for OA. Cultured BMSCs have had beneficial effects in cell-culture models of osteoarthritis including their differentiation into chondrocytes [73] and inhibiting inflammation [74]. BMSCs have had positive effects in a large animal model of OA that was used in support of a larger human program. Specifically, culture-expanded BMSCs stimulated the regeneration of meniscal tissue and slowed the progression of $\mathrm{OA}$ in a medial meniscus excision/anterior cruciate resection goat model [75]. However, these large animal positive results did not translate into regulatory approvals in humans. In a Phase I/II clinical study, 55 patients who underwent a partial medial meniscectomy received two doses of allogeneic mesenchymal stem cells and a vehicle control. While the cells showed safety and there was some new meniscal tissue evident in a portion of subjects twelve months post-meniscectomy [76], the study sponsor did not proceed to a confirmatory trial. Currently, there are no approved cultured stem cell therapies for treatment of osteoarthritis in the United States. Potential gaps in translation of these stem cells include a lack of clear phenotypic parameters for the cells, no set mechanism of action to optimize, and a complex manufacturing process [77]. Together, these data and history suggest that if cBMA has a role in addressing $\mathrm{OA}$, then other non-stem cell components must play a significant role.

There has been significant characterization work performed on cBMA. cBMA contains a high concentration of WBC and therefore has a high concentration of IL-1ra [78]. Indeed, there is a strong and significant correlation between the WBC concentration in cBMA with IL-1ra $\left(R^{2}=0.92\right)$ [14]. In addition to IL-1ra, cBMA contains high concentrations of other anti-inflammatory cytokines like sIL-1RII, sTNF-RI, and sTNF-RII and low concentrations of inflammatory cytokines like IL- $1 \beta$ and TNF $\alpha$ (Table 1 ). Interestingly, cBMA is the only autologous therapy where the ratio of IL-1ra:IL- $1 \beta$ decreases in the concentrated version over the starting material (Table 1 ). While still very low, this is due to an increase in IL-1 $\beta$ by almost 4-fold ( $3.0 \pm 1.1 \mathrm{pg} / \mathrm{mL}$ in BMA and $14.5 \pm 11.4 \mathrm{pg} / \mathrm{mL}$ in cBMA). However, cBMA has by far the most IL-1ra concentration of any autologous blood product with an average of $73,978 \pm 39,464 \mathrm{pg} / \mathrm{mL}$.

Just as with PRP, cBMA has significant concentrations of anabolic and angiogenic growth factors such as TGF- $\beta 1$, PDGF-AB, PDGF-BB, and EGF [14]. These trophic factors are also secreted from cultured mesenchymal stem cells in culture through extracellular 
vesicles (EVs). EVs could be a method to utilize the signal factors from allogenic cell sources such as umbilical cord or Wharton's jelly. EVs from MSCs have been shown to be chondroprotective and anti-inflammatory in cell culture, improve histology scores in both RA and OA animal models, and demonstrates early promise in Phase I/II clinical studies [79].

In addition to IL-1ra, the WBC concentration in cBMA is also significantly correlated with colony forming units-fibroblasts (CFU-F) [80], which is a surrogate marker for BMSCs [81]. cBMA has other progenitor cells including concentrated HSCs and EPCs [82], whose intra-articular role in osteoarthritis has not been extensively characterized. These separate anti-inflammatory and pro-angiogenic properties of cBMA could have differential effects when its injected in different locations.

cBMA is delivered to an OA joint via intra-articular injection. However, cBMA has been used in cartilage repair techniques in combination with varying biomaterials and drug delivery systems including hydrogels and microspheres, and in combination with microfracture surgery. These delivery techniques are intended to increase their residence time and bioavailability of the bioactive factors released from the cells [83]. These approaches have produced durable pain relief in several single-arm studies [84-86]. The intra-articular injection of cBMA for treatment of OA has produced mixed results in randomized and controlled trials. For example, in one study 25 patients with bilateral knee pain received injections of saline in one knee and cBMA in the contralateral knee. Clinical improvements were seen in both knees, but there wasn't a statistical difference between saline and cBMA [59]. In another study, 90 patients with symptomatic knee OA received intraarticular injection of either PRP or cBMA. Both groups had clinically improved symptoms 12 months post-injection, but there were not significant differences between groups. To date, clinical evidence has demonstrated relief of OA symptoms but has not demonstrated reliably that they regrow lost cartilage tissue in OA.

A recent model of OA has been put forward which conceptualizes the "joint as an organ." Subchondral bone plays an important role in OA. Indeed, changes in subchondral bone can alter the function and pain of the whole joint [87-89]. Bone marrow lesions are hypothesized to originate from a traumatic event and have been shown to correlate with pain [90-92]. The proposed mechanism of action for cBMA in these lesions could be its angiogenic molecules and cells recruiting new blood vessels and bone turnover in the lesion, restoring bone health [93]. In a canine subchondral bone lesion model, cBMA and calcium phosphate-injected lesions enhanced knee range of motion and limb loading through improved trabecular bone remodeling [94]. Direct injection of cBMA into an avascular necrosis defect along with decompression has also demonstrated some promise [95]. This general approach of delivering cBMA with or without a carrier has been explored in clinical case series [96-98]. However, further clinical evidence would likely be required.

\section{Conclusions}

There is significant interest in autologous therapies to treat OA patients, both to alleviate symptoms and to potentially delay progression of the disease. While there has been a focus on the differences between these therapies, particularly the presence or absences of white blood cells, the cell culture and animal studies suggest more in common than not. As we examine the mechanistic evidence of each of the therapies, they all have in common the production of anti-inflammatory cytokines at varying concentrations that can be shown both in cell culture and in animal models to delay disease progression. If autologous therapies' mechanism of action is via modifying the local inflammatory environment in the joint, and PRP, AAIs, and cBMA have significant concentrations of anti-inflammatory cytokines, this could explain why all three therapies have demonstrated some level of clinical efficacy. It may be true that the proliferative cytokines derived from platelets, and found in all three therapies, may also play a role in OA, though beneficial effects have been demonstrated in preclinical models but not yet in a clinical setting. 
To date, clinical evidence suggests that they can all alleviate symptoms from patients with OA, but have not yet definitively demonstrated disease modification. Correlations between autologous therapy content and clinical outcomes have been the holy grail in autologous therapies. There is early evidence that potentially the IL-1ra:IL- $1 \mathrm{~b}$ ratio in the output of the therapy may play a role. This fact challenges the dogma that white blood cells, whether sourced from peripheral blood or from bone marrow, should be eliminated from autologous therapies altogether in the treatment of OA. Further studies will be needed to confirm these hypotheses explored in this review. Ultimately, convincing clinical evidence of disease modification will require long-term studies that utilize imaging or other surrogate markers including biomarkers or delay of total joint replacement.

Author Contributions: J.W.-M., K.S., and W.K. drafted, reviewed, and edited this manuscript. All authors have read and agreed to the published version of the manuscript.

Funding: This review received no external funding.

Institutional Review Board Statement: Not applicable.

Informed Consent Statement: Not applicable.

Data Availability Statement: The data presented in this study are available on request from the corresponding author.

Conflicts of Interest: J.W.-M. and K.S. are paid employees of Zimmer Biomet and W.K. is a paid employee of Owl Manor.

\section{References}

1. Aigner, T.; Schmitz, N. Pathogenesis and pathology of osteoarthritis. Rheumatology 2011, 7, 1741-1759.

2. Lequesne, M.G.; Dang, N.; Lane, N.E. Sport practice and osteoarthritis of the limbs. Osteoarthr. Cartil. 1997, 5, 75-86. [CrossRef]

3. Brzusek, D.; Petron, D. Treating knee osteoarthritis with intra-articular hyaluronans. Curr. Med. Res. Opin. 2008, 24, 3307-3322. [CrossRef]

4. Fernandes, J.C.; Martel-Pelletier, J.; Pelletier, J.P. The role of cytokines in osteoarthritis pathophysiology. Biorheology 2002, 39, 237-246. [PubMed]

5. Goldring, M.B.; Otero, M.; Tsuchimochi, K.; Ijiri, K.; Li, Y. Defining the roles of inflammatory and anabolic cytokines in cartilage metabolism. Ann. Rheum. Dis. 2008, 67 (Suppl. 3), iii75-iii82. [CrossRef] [PubMed]

6. Shlopov, B.V.; Gumanovskaya, M.L.; Hasty, K.A. Autocrine regulation of collagenase 3 (matrix metalloproteinase 13) during osteoarthritis. Arthritis Rheumatol. 2000, 43, 195-205. [CrossRef]

7. Goldring, S.R.; Goldring, M.B. The role of cytokines in cartilage matrix degeneration in osteoarthritis. Clin. Orthop. Relat. Res. 2004, 427, S27-S36. [CrossRef] [PubMed]

8. Dinarello, C.A. The role of the interleukin-1-receptor antagonist in blocking inflammation mediated by interleukin-1. N. Eng. J. Med. 2000, 343, 732-734. [CrossRef]

9. Symons, J.A.; Young, P.R.; Duff, G.W. Soluble type II interleukin 1 (IL-1) receptor binds and blocks processing of IL-1 beta precursor and loses affinity for IL-1 receptor antagonist. Proc. Natl. Acad. Sci. USA 1995, 92, 1714-1718. [CrossRef]

10. Van Zee, K.J.; Kohno, T.; Fischer, E.; Rock, C.S.; Moldawer, L.L.; Lowry, S.F. Tumor necrosis factor soluble receptors circulate during experimental and clinical inflammation and can protect against excessive tumor necrosis factor alpha in vitro and in vivo. Proc. Natl. Acad. Sci. USA 1992, 89, 4845-4849. [CrossRef]

11. Giudice, A.; Esposito, M.; Bennardo, F.; Brancaccio, Y.; Buti, J.; Fortunato, L. Dental extractions for patients on oral antiplatelet: A within-person randomised controlled trial comparing haemostatic plugs, advanced-platelet-rich fibrin (A-PRF+) plugs, leukocyteand platelet-rich fibrin (L-PRF) plugs and suturing alone. Int. J. Oral Implant. 2019, 12, 77-87.

12. King, W.J.; Steckbeck, K.; O'Shaughnessey, K.M.; Woodell-May, J. Effect of Preparation Technique on Anti-Inflammatory Properties of Autologous Therapies; Orthopaedic Research Society: Las Vegas, NV, USA, 2015.

13. Steckbeck, K.; Woodell-May, J. Characterization Comparison of Patient-Matched Autologous Therapy Product Concentrations; Orthopaedic Research Society: Phoenix, AZ, USA, 2020.

14. King, W.; Tan, M.; Ponticiello, M.; Woodell-May, J. Anti-Inflammatory Properties of the Output of an Autologous Bone Marrow Concentrating Device; Orthopaedic Research Society: Orlando, FL, USA, 2016.

15. Akeda, K.; An, H.S.; Okuma, M.; Attawia, M.; Miyamoto, K.; Thonar, E.J.; Lenz, M.E.; Sah, R.L.; Masuda, K. Platelet-Rich Plasma Stimulates Porcine Articular Chondrocyte Proliferation and Matrix Biosynthesis. Osteoarthr. Cartil. 2006, 14, 1272-1280. [CrossRef]

16. Cavallo, C.; Filardo, G.; Mariani, E.; Kon, E.; Marcacci, M.; Pereira Ruiz, M.T.; Facchini, A.; Grigolo, B. Comparison of platelet-rich plasma formulations for cartilage healing: An in vitro study. J. Bone Jt. Surg. Am. 2014, 96, 423-429. [CrossRef] 
17. Sundman, E.A.; Cole, B.J.; Fortier, L.A. Growth factor and catabolic cytokine concentrations are influenced by the cellular composition of platelet-rich plasma. Am. J. Sports Med. 2011, 39, 2135-2140. [CrossRef] [PubMed]

18. Arend, W.P.; Malyak, M.; Guthridge, C.J.; Gabay, C. Interleukin-1 receptor antagonist: Role in biology. Annu. Rev. Immunol. 1998, 16, 27-55. [CrossRef]

19. McColl, S.R.; Paquin, R.; Menard, C.; Beaulieu, A.D. Human neutrophils produce high levels of the interleukin 1 receptor antagonist in response to granulocyte/macrophage colony-stimulating factor and tumor necrosis factor alpha. J. Exp. Med. 1992, 176, 593-598. [CrossRef]

20. Dinarello, C.A.; Thompson, R.C. Blocking IL-1: Interleukin 1 receptor antagonist in vivo and in vitro. Immunol. Today 1991, 12, 404-410. [CrossRef]

21. Braun, H.J.; Kim, H.J.; Chu, C.R.; Dragoo, J.L. The effect of platelet-rich plasma formulations and blood products on human synoviocytes implications for intra-articular injury and therapy. Am. J. Sports Med. 2014, 42, 1204-1210. [CrossRef]

22. Mariani, E.; Canella, V.; Cattini, L.; Kon, E.; Marcacci, M.; Di Matteo, B.; Pulsatelli, L.; Filardo, G. Leukocyte-Rich Platelet-Rich Plasma Injections Do Not. Up-Modulate Intra-Articular Pro-Inflammatory Cytokines in the Osteoarthritic Knee. PLoS ONE 2016, 11, e0156137. [CrossRef]

23. Arend, W.P. The mode of action of cytokine inhibitors. J. Rheumatol. Suppl. 2002, 65, 16-21. [PubMed]

24. Cuéllar, J.M.; Cuéllar, V.G.; Scuderi, G.J. $\alpha(2)-M a c r o g l o b u l i n:$ Autologous Protease Inhibition Technology. Phys. Med. Rehabil. Clin. N. Am. 2016, 27, 909-918. [CrossRef]

25. Milano, G.; Deriu, L.; Sanna, P.E.; Masala, G.; Manunta, A.; Postacchini, R.; Saccomanno, M.F.; Fabbriciani, C. Repeated platelet concentrate injections enhance reparative response of microfractures in the treatment of chondral defects of the knee: An experimental study in an animal model. Arthroscopy 2012, 28, 688-701. [CrossRef]

26. Sun, Y.; Feng, Y.; Zhang, C.Q.; Chen, S.B.; Cheng, X.G. The regenerative effect of platelet-rich plasma on healing in large osteochondral defects. Int. Orthop. 2010, 34, 589-597. [CrossRef]

27. Kwon, D.R.; Park, G.Y.; Lee, S.U. The effects of intra-articular platelet-rich plasma injection according to the severity of collagenaseinduced knee osteoarthritis in a rabbit model. Ann. Rehabil. Med. 2012, 36, 458-465. [CrossRef]

28. Saito, M.; Takahashi, K.A.; Arai, Y.; Inoue, A.; Sakao, K.; Tonomura, H.; Honjo, K.; Nakagawa, S.; Inoue, H.; Tabata, Y.; et al Intraarticular administration of platelet-rich plasma with biodegradable gelatin hydrogel microspheres prevents osteoarthritis progression in the rabbit knee. Clin. Exp. Rheumatol. 2009, 27, 201-207.

29. Fahie, M.A.; Ortolano, G.A.; Guercio, V.; Schaffer, J.A.; Johnston, G.; Au, J.; Hettlich, B.A.; Phillips, T.; Allen, M.J.; Bertone, A.L. A randomized controlled trial of the efficacy of autologous platelet therapy for the treatment of osteoarthritis in dogs. J. Am. Vet. Med. Assoc. 2013, 243, 1291-1297. [CrossRef] [PubMed]

30. Cole, B.J.; Karas, V.; Hussey, K.; Merkow, D.B.; Pilz, K.; Fortier, L.A. Hyaluronic Acid Versus Platelet-Rich Plasma: A Prospective, Double-Blind. Randomized Controlled Trial Comparing Clinical Outcomes and Effects on Intra-articular Biology for the Treatment of Knee Osteoarthritis. Am. J. Sports Med. 2017, 45, 339-346. [CrossRef] [PubMed]

31. Filardo, G.; Kon, E.; Pereira Ruiz, M.T.; Vaccaro, F.; Guitaldi, R.; Di, M.A.; Cenacchi, A.; Fornasari, P.M.; Marcacci, M. Platelet-rich plasma intra-articular injections for cartilage degeneration and osteoarthritis: Single- versus double-spinning approach. Knee Surg. Sports Traumatol. Arthrosc. 2011, 20, 2082-2091. [CrossRef]

32. Wehling, P.; Moser, C.; Frisbie, D.; Mcllwraith, C.W.; Kawcak, C.E.; Krauspe, R.; Reinecke, J.A. Autologous conditioned serum in the treatment of orthopedic diseases: The orthokine therapy. BioDrugs 2007, 21, 323-332. [CrossRef]

33. O'Shaughnessey, K.; Matuska, A.; Hoeppner, J.; Farr, J.; Klaassen, M.; Kaeding, C.; Lattermann, C.; King, W.; Woodell-May, J. Autologous protein solution prepared from the blood of osteoarthritic patients contains an enhanced profile of anti-inflammatory cytokines and anabolic growth factors. J. Orthop. Res. 2014, 32, 1349-1355. [CrossRef]

34. King, W.J.; Toler, K.; Woodell-May, J. White Blood Cell Concentration Correlates with Increased Concentrations of IL-1ra and Changes in WOMAC Pain Scores in an Open-Label. Safety Study of Autologous Protein Solution. Exp. Orthop. $2016,3,9$. [CrossRef] [PubMed]

35. Woodell-May, J.E.; Matuska, A.; Oyster, M.; Welch, Z.; O'Shaughnessey, K.M.; Hoeppner, J. Autologous protein solution inhibits MMP-13 production by IL-1beta and TNFalpha-stimulated human articular chondrocytes. J. Orthop. Res. 2011, 29, 1320-1326. [CrossRef] [PubMed]

36. Kon, E.; Engebretsen, L.; Verdonk, P.; Nehrer, S.; Filardo, G. Clinical outcomes of knee osteoarthritis treated with an autologous protein solution injection: A 1-year pilot double-blinded randomized controlled trial. Am. J. Sports Med. 2018, 46, 171-180. [CrossRef]

37. Hix, J.; Klaassen, M.; Foreman, R.; Cullen, E.; Toler, K.; King, W.; Woodell-May, J.A. Autologous Anti-Inflammatory Protein Solution Yielded a Favorable Safety Profile and Significant Pain Relief in an Open-Label. Pilot Study of Patients with Osteoarthritis. Biores. Open Access. 2017, 6, 151-158. [CrossRef] [PubMed]

38. Matuska, A.; O'Shaughnessey, K.; King, W.; Woodell-May, J. Autologous solution protects bovine cartilage explants from IL-1 $\alpha$-and TNF $\alpha$-induced cartilage degradation. J. Orthop. Res. 2013, 31, 1929-1935. [CrossRef] [PubMed]

39. Wojdasiewicz, P.A.; Poniatowski, Ł.; Szukiewicz, D. The role of inflammatory and anti-inflammatory cytokines in the pathogenesis of osteoarthritis. Mediat. Inflamm. 2014, 2014, 561459. [CrossRef]

40. O'Shaughnessey, K.M.; Panitch, A.; Woodell-May, J.E. Blood-derived anti-inflammatory protein solution blocks the effect of IL-1b on human macrophages in vitro. Inflamm. Res. 2011, 60, 929-936. [CrossRef] 
41. Velloso Alvarez, A.; Boone, L.H.; Pondugula, S.R.; Caldwell, F.; Wooldridge, A.A. Effects of Autologous Conditioned Serum, Autologous Protein Solution, and Triamcinolone on Inflammatory and Catabolic Gene Expression in Equine Cartilage and Synovial Explants Treated With IL-1 $\beta$ in Co-culture. Front. Vet. Sci. 2020, 7, 323. [CrossRef]

42. King, W.; Bendele, A.; Marohl, T.; Woodell-May, J. Human blood-based anti-inflammatory solution inhibits osteoarthritis progression in a meniscal-tear rat study. J. Orthop. Res. 2017, 35, 2260-2268. [CrossRef]

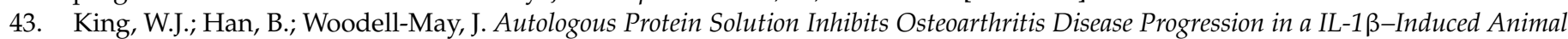
Model; Orthopaedic Research Society Meeting: San Diego, CA, USA, 2017.

44. Bertone, A.L.; Ishihara, A.; Zekas, L.J.; Wellman, M.L.; Lewis, K.B.; R, S.; Barnaba, A.; Schmall, M.L.; Kanter, P.M.; Genovese, R.L. Evaluation of a single intra-articular injection of autologous protein solution for treatment of osteoarthritis in horses. Am. J. Vet. Res. 2014, 75, 141-151. [CrossRef]

45. Wanstrath, A.; Hettlich, B.A.; Su, L.; Smith, A.; Zekas, L.J.; Allen, A.J.; Bertone, A.L. Evaluation of a single intra-articular injection of autologous protein solution for treatment of osteoarthritis in a canine population. Vet. Surg. 2016, 45, 764-774. [CrossRef] [PubMed]

46. Wasai, S.; Sato, M.; Maehara, M.; Toyoda, E.; Uchiyama, R.; Takahashi, T.; Okada, E.; Iwasaki, Y.; Suzuki, S.; Watanabe, M. Characteristics of autologous protein solution and leucocyte-poor platelet-rich plasma for the treatment of osteoarthritis of the knee. Sci. Rep. 2020, 10, 10572. [CrossRef] [PubMed]

47. King, W.J.; VanDerWeegen, W.; Van Drumpt, R.; Soons, H.; Toler, K.; Woodell-May, J.E. Characterizing the Relationship between White Blood Cell and IL-1ra Concentration in Whole Blood and Decreased Osteoarthritis Pain in an Open-Label. Study of Autologous Protein Solution. In Proceedings of the European Federation of National Associations of Orthopaedics \& Traumatology Congress, 16th Annual Meeting, Prague, Czech Republic, 27-29 May 2015.

48. Darshan, S.A.; Navraj Atwal, H.M. Autologous cell-free serum preparations in the management of knee osteoarthritis: What is the current clinical evidence? Knee Surg. Relat. Res. 2020, 32, 1-10.

49. Yang, K.G.; Raijmakers, N.J.; van Arkel, E.R.; Caron, J.J.; Rijk, P.C.; Willems, W.J.; Zijl, J.A.; Verbout, A.J.; Dhert, W.J.; Saris, D.B. Autologous interleukin-1 receptor antagonist improves function and symptoms in osteoarthritis when compared to placebo in a prospective randomized controlled trial. Osteoarthr. Cartil. 2008, 16, 498-505. [CrossRef] [PubMed]

50. Baltzer, A.W.; Moser, C.; Jansen, S.A.; Krauspe, R. Autologous conditioned serum (Orthokine) is an effective treatment for knee osteoarthritis. Osteoarthr. Cartil. 2008, 17, 152-160. [CrossRef] [PubMed]

51. Van Drumpt, R.A.M.; van Der Weegen, W.; King, W.J.; Toler, K.; Macenski, M.M. Safety and Treatment Effectiveness of a Single Autologous Protein Solution Injection in Patients with Knee Osteoarthritis. Biores. Open Access 2016, 5, 261-268. [CrossRef] [PubMed]

52. Van Genechten, W.; Vuylsteke, K.; Swinnen, L.; Martinez, P.R.; Verdonk, P. Autologous protein solution as selective treatment for advanced patellofemoral osteoarthritis in the middle-aged female patient: $54 \%$ response rate at 1 year follow-up. Knee Surg. Sports Traumatol. Arthrosc. 2021, 29, 988-997. [CrossRef]

53. Kon, E.; Engebretsen, L.; Verdonk, P.; Nehrer, S.; Filardo, G. Autologous Protein Solution Injections for the Treatment of Knee Osteoarthritis: 3-Year Results. Am. J. Sports Med. 2020, 48, 2703-2710. [CrossRef] [PubMed]

54. Jagodzinski, M.; Liu, C.; Guenther, D.; Burssens, A.; Petri, M.; Abedian, R.; Willbold, E.; Krettek, C.; Haasper, C.; Witte, F. Bone marrow-derived cell concentrates have limited effects on osteochondral reconstructions in the mini pig. Tissue Eng. Part C Methods 2014, 20, 215-226. [CrossRef]

55. Desando, G.; Bartolotti, I.; Cavallo, C.; Schiavinato, A.; Secchieri, C.; Kon, E.; Filardo, G.; Paro, M.; Grigolo, B. Short-term homing of hyaluronan-primed cells: Therapeutic implications for osteoarthritis treatment. Tissue Eng. Part C Methods 2018, 24, 121-133. [CrossRef]

56. Wang, Z.; Zhai, C.; Fei, H.; Hu, J.; Cui, W.; Wang, Z.; Li, Z.; Fan, W. Intraarticular injection autologous platelet-rich plasma and bone marrow concentrate in a goat osteoarthritis model. J. Orthop. Res. 2018, 36, 2140-2146. [CrossRef]

57. Song, F.; Tang, J.; Geng, R.; Hu, H.; Zhu, C.; Cui, W.; Fan, W. Comparison of the efficacy of bone marrow mononuclear cells and bone mesenchymal stem cells in the treatment of osteoarthritis in a sheep model. Int. J. Clin. Exp. Pathol. 2014, 7, 1415. [PubMed]

58. Singh, A.; Goel, S.; Gupta, K.; Kumar, M.; Arun, G.; Patil, H.; Kumaraswamy, V.; Jha, S. The role of stem cells in osteoarthritis: An experimental study in rabbits. Bone Jt. Res. 2014, 3, 32-37. [CrossRef] [PubMed]

59. Shapiro, S.A.; Kazmerchak, S.E.; Heckman, M.G.; Zubair, A.C.; O'Connor, M.I. A prospective, single-blind, placebo-controlled trial of bone marrow aspirate concentrate for knee osteoarthritis. Am. J. Sports Med. 2017, 45, 82-90. [CrossRef] [PubMed]

60. Chahla, J.; Dean, C.S.; Moatshe, G.; Pascual-Garrido, C.; Serra Cruz, R.; LaPrade, R.F. Concentrated bone marrow aspirate for the treatment of chondral injuries and osteoarthritis of the knee: A systematic review of outcomes. Orthop. J. Sports Med. 2016, 4, 2325967115625481. [CrossRef]

61. Mautner, K.; Bowers, R.; Easley, K.; Fausel, Z.; Robinson, R. Functional Outcomes Following Microfragmented Adipose Tissue Versus Bone Marrow Aspirate Concentrate Injections for Symptomatic Knee Osteoarthritis. Stem Cells Transl. Med. 2019, 8, 1149-1156. [CrossRef] [PubMed]

62. Themistocleous, G.S.; Chloros, G.D.; Kyrantzoulis, I.M.; Georgokostas, I.A.; Themistocleous, M.S.; Papagelopoulos, P.J.; Savvidou, O.D. Effectiveness of a single intra-articular bone marrow aspirate concentrate (BMAC) injection in patients with grade 3 and 4 knee osteoarthritis. Heliyon 2018, 4, e00871. [CrossRef] 
63. Hernigou, P.; Bouthors, C.; Bastard, C.; Lachaniette, C.H.F.; Rouard, H.; Dubory, A. Subchondral bone or intra-articular injection of bone marrow concentrate mesenchymal stem cells in bilateral knee osteoarthritis: What better postpone knee arthroplasty at fifteen years? A randomized study. Int. Orthop. 2020, 45, 391-399. [CrossRef] [PubMed]

64. Ha, C.-W.; Park, Y.-B. Editorial Commentary: Considering Clinical Application of Bone Marrow Aspirate Concentrate for Restoration of Cartilage Defects in the Knee? Is It a Kind of Stem Cell Therapy? Arthroscopy 2019, 35, 1878-1879. [CrossRef]

65. King, W.; Toler, K.; Woodell-May, J. Role of White Blood Cells in Blood-and Bone Marrow-Based Autologous Therapies. Biomed. Res. Int. 2018, 2018. [CrossRef]

66. Cheshier, S.H.; Morrison, S.J.; Liao, X.; Weissman, I.L. In vivo proliferation and cell cycle kinetics of long-term self-renewing hematopoietic stem cells. Proc. Natl. Acad. Sci. USA 1999, 96, 3120-3125. [CrossRef]

67. Pittenger, M.F.; Mackay, A.M.; Beck, S.C.; Jaiswal, R.K.; Douglas, R.; Mosca, J.D.; Moorman, M.A.; Simonetti, D.W.; Craig, S.; Marshak, D.R. Multilineage potential of adult human mesenchymal stem cells. Science 1999, 284, 143-147. [CrossRef]

68. Asahara, T.; Masuda, H.; Takahashi, T.; Kalka, C.; Pastore, C.; Silver, M.; Kearne, M.; Magner, M.; Isner, J.M. Bone marrow origin of endothelial progenitor cells responsible for postnatal vasculogenesis in physiological and pathological neovascularization. Circ. Res. 1999, 85, 221-228. [CrossRef] [PubMed]

69. Caplan, A.I. Mesenchymal stem cells: Cell-based reconstructive therapy in orthopedics. Tissue Eng. 2005, 11, 1198-1211. [CrossRef] [PubMed]

70. Sacchetti, B.; Funari, A.; Michienzi, S.; Di Cesare, S.; Piersanti, S.; Saggio, I.; Tagliafico, E.; Ferrari, S.; Robey, P.G.; Riminucci, M. Self-renewing osteoprogenitors in bone marrow sinusoids can organize a hematopoietic microenvironment. Cell 2007, 131, 324-336. [CrossRef]

71. Hernigou, P.; Homma, Y.; Lachaniette, C.H.F.; Poignard, A.; Allain, J.; Chevallier, N.; Rouard, H. Benefits of small volume and small syringe for bone marrow aspirations of mesenchymal stem cells. Int. Orthop. 2013, 37, 2279-2287. [CrossRef]

72. Marx, R.E.; Tursun, R. A qualitative and quantitative analysis of autologous human multipotent adult stem cells derived from three anatomic areas by marrow aspiration: Tibia, anterior ilium, and posterior ilium. Int. J. Oral Maxillofac. Implant. 2013, 28, e290-e294. [CrossRef]

73. Richardson, S.M.; Curran, J.M.; Chen, R.; Vaughan-Thomas, A.; Hunt, J.A.; Freemont, A.J.; Hoyland, J.A. The differentiation of bone marrow mesenchymal stem cells into chondrocyte-like cells on poly-L-lactic acid (PLLA) scaffolds. Biomaterials 2006, 27, 4069-4078. [CrossRef] [PubMed]

74. Van Buul, G.; Villafuertes, E.; Bos, P.; Waarsing, J.; Kops, N.; Narcisi, R.; Weinans, H.; Verhaar, J.; Bernsen, M.; Van Osch, G. Mesenchymal stem cells secrete factors that inhibit inflammatory processes in short-term osteoarthritic synovium and cartilage explant culture. Osteoarthr. Cartil. 2012, 20, 1186-1196. [CrossRef] [PubMed]

75. Murphy, J.M.; Fink, D.J.; Hunziker, E.B.; Barry, F.P. Stem cell therapy in a caprine model of osteoarthritis. Arthritis Rheum. Off. J. Am. Coll. Rheumatol. 2003, 48, 3464-3474. [CrossRef]

76. Vangsness, C.T., Jr.; Farr, J.I.; Boyd, J.; Dellaero, D.T.; Mills, C.R.; LeRoux-Williams, M. Adult human mesenchymal stem cells delivered via intra-articular injection to the knee following partial medial meniscectomy: A randomized, double-blind, controlled study. JBJS 2014, 96, 90-98. [CrossRef] [PubMed]

77. Barry, F. MSC therapy for osteoarthritis: An unfinished story. J. Orthop. Res. 2019, 37, 1229-1235. [CrossRef]

78. Cassano, J.M.; Kennedy, J.G.; Ross, K.A.; Fraser, E.J.; Goodale, M.B.; Fortier, L.A. Bone marrow concentrate and platelet-rich plasma differ in cell distribution and interleukin 1 receptor antagonist protein concentration. Knee Surg. Sports Traumatol. Arthrosc. 2018, 26, 333-342. [CrossRef] [PubMed]

79. Arrigoni, C.; D’Arrigo, D.; Rossella, V.; Candrian, C.; Albertini, V.; Moretti, M. Umbilical Cord MSCs and Their Secretome in the Therapy of Arthritic Diseases: A Research and Industrial Perspective. Cells 2020, 9, 1343. [CrossRef]

80. Han, B.; Tan, M.; King, W.; Woodell-May, J. White blood cell concentration correlates with CFU-F concentration in the output of a point-of-care bone marrow concentrating device. In TERMIS; European Cells and Materials: Uppsala, Sweden, 2016.

81. Friedenstein, A.J.; Gorskaja, J.; Kulagina, N. Fibroblast precursors in normal and irradiated mouse hematopoietic organs. Exp. Hematol. 1976, 4, 267.

82. Woodell-May, J.E.; Tan, M.L.; King, W.J.; Swift, M.J.; Welch, Z.R.; Murphy, M.P.; McKale, J.M. Characterization of the cellular output of a point-of-care device and the implications for addressing critical limb ischemia. Biores. Open Access 2015, 4, 417-424. [CrossRef] [PubMed]

83. Patel, J.M.; Saleh, K.S.; Burdick, J.A.; Mauck, R.L. Bioactive factors for cartilage repair and regeneration: Improving delivery, retention, and activity. Acta Biomater. 2019, 93, 222-238. [CrossRef]

84. Skowroński, J.; Rutka, M. Osteochondral lesions of the knee reconstructed with mesenchymal stem cells-results. Ortop. Traumatol. Rehabil. 2013, 15, 195-204. [CrossRef]

85. De Girolamo, L.; Schönhuber, H.; Viganò, M.; Bait, C.; Quaglia, A.; Thiebat, G.; Volpi, P. Autologous matrix-induced chondrogenesis (amic) and amic enhanced by autologous concentrated bone marrow aspirate (bmac) allow for stable clinical and functional improvements at up to 9 years follow-up: Results from a randomized controlled study. J. Clin. Med. 2019, 8, 392. [CrossRef]

86. Enea, D.; Cecconi, S.; Calcagno, S.; Busilacchi, A.; Manzotti, S.; Gigante, A. One-step cartilage repair in the knee: Collagen-covered microfracture and autologous bone marrow concentrate. A pilot study. Knee 2015, 22, 30-35. [CrossRef]

87. Radin, E.L.; Rose, R.M. Role of subchondral bone in the initiation and progression of cartilage damage. Clin. Orthop. Relat. Res. 1986, 213, 34-40. [CrossRef] 
88. Madry, H.; van Dijk, C.N.; Mueller-Gerbl, M. The basic science of the subchondral bone. Knee Surg. Sports Traumatol. Arthrosc. 2010, 18, 419-433. [CrossRef] [PubMed]

89. Buckwalter, J. Articular cartilage injuries. Clin. Orthop. Relat. Res. 2002, 402, 21-37. [CrossRef]

90. Koo, K.-H.; Ahn, I.-O.; Kim, R.; Song, H.-R.; Jeong, S.-T.; Na, J.-B.; Kim, Y.-S.; Cho, S.-H. Bone marrow edema and associated pain in early stage osteonecrosis of the femoral head: Prospective study with serial MR images. Radiology 1999, 213, 715-722. [CrossRef]

91. Felson, D.T.; Chaisson, C.E.; Hill, C.L.; Totterman, S.M.; Gale, M.E.; Skinner, K.M.; Kazis, L.; Gale, D.R. The association of bone marrow lesions with pain in knee osteoarthritis. Ann. Intern. Med. 2001, 134, 541-549. [CrossRef] [PubMed]

92. Felson, D.T.; Niu, J.; Guermazi, A.; Roemer, F.; Aliabadi, P.; Clancy, M.; Torner, J.; Lewis, C.E.; Nevitt, M.C. Correlation of the development of knee pain with enlarging bone marrow lesions on magnetic resonance imaging. Arthritis Rheum. Off. J. Am. Coll. Rheumatol. 2007, 56, 2986-2992. [CrossRef] [PubMed]

93. Stoker, A.M.; Baumann, C.A.; Stannard, J.P.; Cook, J.L. Bone marrow aspirate concentrate versus platelet rich plasma to enhance osseous integration potential for osteochondral allografts. J. Knee Surg. 2018, 31, 314-320.

94. Oliver, H.A.; Bozynski, C.C.; Cook, C.R.; Kuroki, K.; Sherman, S.L.; Stoker, A.M.; Cook, J.L. Enhanced Subchondroplasty Treatment for Post-Traumatic Cartilage and Subchondral Bone Marrow Lesions in a Canine Model. J. Orthop. Res. 2020, 38, 740-746. [CrossRef] [PubMed]

95. Martin, J.R.; Houdek, M.T.; Sierra, R.J. Use of concentrated bone marrow aspirate and platelet rich plasma during minimally invasive decompression of the femoral head in the treatment of osteonecrosis. Croat. Med. J. 2013, 54, 219-224. [CrossRef] [PubMed]

96. Kasik, C.S.; Martinkovich, S.; Mosier, B.; Akhavan, S. Short-Term Outcomes for the Biologic Treatment of Bone Marrow Edema of the Knee Using Bone Marrow Aspirate Concentrate and Injectable Demineralized Bone Matrix. Arthrosc. Sports Med. Rehabil. 2019, 1, e7-e14. [CrossRef] [PubMed]

97. Ankem, H.K.; Diulus, S.C.; Maldonado, D.R.; Ortiz-Declet, V.; Rosinsky, P.J.; Meghpara, M.B.; Shapira, J.; Lall, A.C.; Domb, B.G. Arthroscopic-Assisted Intraosseous Bioplasty of the Acetabulum. Arthrosc. Tech. 2020, 9, e1531-e1539. [CrossRef] [PubMed]

98. Hood, J.R.C.R.; Miller, J.R. The triad of osteobiology-Rehydrating calcium phosphate with bone marrow aspirate concentrate for the treatment of bone marrow lesions. Bone 2016, 5, 8 . 